\title{
PENTINGNYA PROFESI GURU DI PENDIDIKAN DI INDONESIA
}

\author{
Anggelika Permata Sari \\ Email: 2010111220001@mhs.ulm.ac.id \\ Program Studi Pendidikan Sejarah Fakultas Keguruan dan Ilmu Pendidikan \\ Universitas Lambung Mangkurat \\ Banjarmasin
}

\begin{abstract}
Abstrak
Profesi dapat diartikan sebagai suatu pekerjaan atau jabatan yang menuntut keahlian, yang didapat melalui Pendidikan dan latihan tertentu, menurut persyaratan khusus memiliki tanggung jawab dan kode etik tertentu. Profesi merupakan suatu kesatuan dari pengetahuan dan keterampilan bahkan jika ditarik dalam duania Pendidikan dalam hal ini adalah guru, maka profesinya sebagai guru harus memilik pengetahuan dan keterampilan dalam bidnag mata pelajaran dan teori Pedidikan. Profesionalisme sangat diperlukan dalam memajukan Pendidikan di Indonesia tentu juga sebagai perilaku kerja yang mengutamakan kesempurnaan hasil mekanisme kerja yang benar, hal ini sangat duperlukan untuk menunjang Pendidikan di Indonesia guru yang benar profesi guru dalam UU No.14 tahun 2005 tentang guru dan dosen mengharuskan sebuah komponen pokok yang harus dimiliki seorang guru professional, kompetensi tersebut adalah kompetensi profesional, kompetensi sosial, dan kompetensi kepribadian.
\end{abstract}

\section{PENDAHULUAN}

Profesi secara etimologis berasal dari bahasa Latin proffesio, yang berarti janji atau ikrar dan pekerjaan. Dalam arti luas profesi dimaksudkan pada kecakupan kegiatan apa saja dan siapa saja untuk memperolah nafkah yang dilakukan dengan keahlian tertentu. Dalam arti sempit profesi berarti kegiatan yang dijalankan berdasarkan keahlian tertentu sekaligus menuntut pelaksanaan norma-norma sosial dengan baik. (Surya, 2003: 203)

Profesi merupakan suatu kesatuan dari pengetahuan dan keterampilan bahkan jika ditarik dalam dunia Pendidikan dalam hal ini adalah guru, maka profesinya sebagai guru harus memiliki pengetahuan dan keterampilan dalam bidang mata pelajaran dan teori Pendidikan. (Sya'bani, 2018: 10)

Berdasarkan UU RI No.14 tahun 2005 tentang Guru dan dosen pasal 1, Guru adalah Pendidikan professional dengan tugas utama mendidik, mengajar, membimbing, mengarahkan, melatih, menilai dan mengevaluasi peserta didik pada Pendidikan anak usia dini jalur Pendidikan formal, Pendidikan dasar, dan Pendidikan menengah. Dosen adalah pendidik professional dan keilmuan dengan tugas utama mentransformasikan, 
mengembangkan, dan menyebarluaskan ilmu pengetahuan, teknologi, dan seni melalui Pendidikan, penelitian, dan pengabdian kepada masyarakat. (Susanto, 2020: 16-17)

\section{PERAN GURU SEBAGAI SEBUAH PROFESI}

Profesi adalah pekerjaan atau jabatan yang menuntut keahlian tertentu. Guru merupakan suatu profesi yang berarti suatu jabatan memerlukan keahlian khusus sebagai guru dan tidak dapat dilakukan oleh sembarang orang diluar bidang Pendidikan. (Susanto, 2020: 17)

Berdasarkan UU RI No.14 tahun 2005 tentang guru dan dosen Pasal 1, Guru adalah pendidik profesional dngan tugas utama mendidik, mengajar, membimbing, mengarahkan, melatih, menili, dan mengevaluasi peserta didik pada Pendidikan anak usia dini jalur Pendidikan formal, Pendidikan dasar, dan Pendidikan menengah. Dosen adalah pendidik professional dan ilmuan dengan tugas utama mentransformasikan, mengembangkan, dan menyebarluaskan ilmu pengetahuan, teknologi, dan seni melalui Pendidikan, penelitian, dan pengabdian kepada masyarakat. (Susanto, 2020: 16)

UU RI No.14 tahun 2005 tentang guru dan dosen pasal 4 disebutkan kedudukan guru sebagai tenaga professional berfungsi untuk meningkatkan martabat dan peran guru sebagai agen pembelajaran berfungsi untuk meningkatkan mutu Pendidikan nasional. Fungsi utama guru yaitu yaitu sebagai agen pembelajaran untuk meningkatkan kualitas Pendidikan secara nasional. Sebagai agen pembelajaran berarti guru merupakan garda terdepan dalam Pendidikan yang secara langsung berperan untuk peningkatan kualitas Pendidikan. (Sya'bani, 2018: 42)

Ahmad D. Marimba menambahkan bahwa pengertian guru yaitu sebagai pendidik yang memiliki hak dan kewajiban terkait Pendidikan peserta didiknya. Dijelaskan bahwa guru memiliki tanggung jawab memberikan bimbingan kepada peserta didik dalam perkembangan jasmani dan rohani agar mencapai tingkat kedewasaaan memenuhi tugasnya sebagai makhluk Tuhan, makhluk indivudu dan makhluk sosial. (Sya'bani, 2018: 35)

UU No. 14 tahun 2005 Pasal 20 yang menyataan dalam melaksanankan tugas keprofesionalan, guru berkewajiban:

a. Merencanakan pembelajaran, melaksanakan proses pembelajaran yang bermutu, serta menilai dan mengevalusai hasil pembelajaran

b. Meningkatkan dan mengembangkan kualifikasi akademik dan kompetensi secara berkelanjutan sejalan dengan perkembangan ilmu pengetahuan, teknologi, dan seni

c. Bertindak objektik dan tidak diskriminatif atas dasar pertimbangan jenis kelamin, agama, suku, ras, dan kondisi fisik tertentu, atau latar belakang keluarga, dan status sosial ekonomi peserta didik dalam pembelajaran

d. Menjunjung tinggi peraturan perundang-undangan, hokum, dan kode etik guru, serta nilai-nilai agama dan etika

e. Memelihara dan memupukpersatuan dan kesatuan bangsa. (Umbara, 2013: 12-13) 


\section{GURU INDONESIA DAN TANTANGAN PROFESIONALISME}

Profesionalisme meunjuk kepada komitmen para anggota suatu profesi untuk meningkatkan kemampuan profesionalnya dan terus menerus mengembangkan strategistrategi yang digunakannya dalam melakukan pekerjaan yang sesuai dengan profesinya. Ahmad Tafsir memberikan pengertian profesionalisme yaitu sebagai paham yang mengajarkan bahwa setiap pekerjaan harus dilakukan oleh orang yang professional. (Tafsir, 1992: 107)

Profesionalisme guru diperlukan untuk memajukan Pendidikan Indonesia karena profesi keguruan mempunyai tugas utama yaitu melayani masyarakat dalam dunia Pendidikan. Untuk meningkatkan mutu Pendidikan saat ini, maka profesional guru merupakan keharusan, terlebih lagi apabila melihat kondisi objektif saat ini berkaitan dengan berbagai hal yang ditemui dalam melaksanakan Pendidikan, yaitu:

1. Perkembangan IPTEK

2. Persaingan global bagi lulusan Pendidikan

3. Otonomi daerah

4. Implementasi kurikulum tingkat satuan Pendidikan (KTSP). (Saud, 2010: 98)

Kompetensi profesional guru ialah kemampuan dan kewenangan guru dalam menjalankan profesi keguruannya, artinya guru yang piawai dalam melaksanakan profesinya dapat disebut sebagai guru yang kompeten dan profesional. Kompetensi profesional merupakan pekerjaan yang hanya dapat di lakukan oleh sorang yang mempunyai kualifikasi akademik, kompetensi dan sertifikat pendidik sesuai dengan persyaratan untuk setiap jenis dan jenjang Pendidikan tertentu. Kompetensi profesional merupakan dasar yang harus dimiliki oleh guru. Ada beberapa pandangan ahli tentang kompetensi profesional guru. Menurut Cooper (1984: 15) terbagi kedalam 4 komponen kompetensi dasar, yakni:

a. Mempunyai pengetahuan tentang belajar dan tingkah laku manusia

b. Mempunyai pengetahuan dan menguasai bidang studi yang dibinanya

c. Mempunyai sikap yang tepat tentang diri sendiri, sekolah, teman sejawat dan bidang studi yang dibinanya

d. Mempunyai keterampilan dalam tekhnik mengajar. (Susanto, 2020: 63)

\section{SIMPULAN}

Profesi adalah pekerjaan atau jabatan yang menuntut keahlian tertentu. Guru merupskan suatu profesi yang berarti suatu jabatan memerlukan keahlian khusus sebagai guru dan tidak dapat dilakukan oleh sembarang orang diluar bidang Pendidikan. UU No.14 tahun 2005 tentang guru dan dosen. Profesionalisme menunjuk kepada komitmen para anggota suatu profesi untuk meningkatkan kemampuan profesionalnya dan terus menerus mengembangkan strategi-strategi yang digunakannya dalam melakukan pekerjaan yang 
sesuai profesinya. Kompetensi profesional guru ialah kemampuan dan kewenangan guru dalam menjalankan profesi kegururannya artinya guru yang piawai dalam melaksanakan profesinya dapat disebut sebagai guru yang kompeten dan profesional.

\section{REFERENSI}

Efendi, I., Prawitasari, M., \& Susanto, H. (2021). Implementasi Penilaian Pembelajaran Pada Kurikulum 2013 Mata Pelajaran Sejarah. Prabayaksa: Journal of History Education, 1(1), 21-25.

Susanto, H. (2020). Profesi Keguruan. Banjarmasin: FKIP Universitas Lambung Mangkurat.

Susanto, H., \& Akmal, H. (2018). Efektivitas Penggunaan Aplikasi Pembelajaran Berbasis Mobile Smartphone Sebagai Media Pengenalan Sejarah Lokal Masa Revolusi Fisik Di Kalimantan Selatan Pada Siswa Sekolah Menengah Atas. HISTORIA: Jurnal Program Studi Pendidikan Sejarah, 6(2), 197-206.

Susanto, H., Irmawati, I., Akmal, H., \& Abbas, E. W. (2021). Media Film Dokumenter Masuknya Islam Ke Nusantara dan Pengaruhnya Terhadap Keterampilan Berpikir Kritis Siswa. HISTORIA: Jurnal Program Studi Pendidikan Sejarah, 9(1).

Syaharuddin, S., \& Susanto, H. (2019). Sejarah Pendidikan Indonesia (Era Pra Kolonialisme Nusantara sampai Reformasi). Banjarmasin: FKIP Universitas Lambung Mangkurat. 